 \\ z Filologii Polskiej i Słowiańskiej}

DOI: $10.11649 /$ sfps. 2390
Article No. 2390

\section{Citation:}

Łuczak, A. (2020). Wykaz publikacji dr hab. Elżbiety Kędelskiej. Studia z Filologii Polskiej i Słowiańskiej, 55, Article 2390. https://doi.org/10.11649/sfps.2390

\author{
Arleta Łuczak \\ (Instytut Slawistyki Polskiej Akademii Nauk, Warszawa)
}

\title{
Wykaz publikacji dr hab. Elżbiety Kędelskiej
}

1978

Kędelska, E. (1978). Polska terminologia medyczna w słownikach Bartłomieja z Bydgoszczy. Studia z Filologii Polskiej i Słowiańskiej, 17, 95-104.

Kwilecka, I., \& Kędelska, E. (1978). Z prac nad nową edycją Słownika Bartłomieja z Bydgoszczy. Studia z Filologii Polskiej i Słowiańskiej, 17, 123-143.

\section{9}

Kędelska, E. (1979). Pierwsze wydanie słownika Mymera i jego stosunek do źródeł. Studia z Filologii Polskiej i Słowiańskiej, 18, 81-92.

\section{1}

Kędelska, E. (1981). Z. Cygal-Krupowa, Szesnastowieczne edycje Dictionarii Ioannis Murmellii variarum rerum..., cz. I. Ortografia, fonetyka, cechy dialektyczne, Warszawa-Kraków 1979 [Recenzja]. Język Polski, 61(1-2), $116-121$.

This is an Open Access article distributed under the terms of the Creative Commons Attribution 3.0 PL License (creativecommons.org/licenses/by/3.0/pl/), which permits redistribution, commercial and non-commercial, provided that the article is properly cited. (C) The Author(s) 2020.

Publisher: Institute of Slavic Studies, Polish Academy of Sciences

[Wydawca: Instytut Slawistyki Polskiej Akademii Nauk] 


\section{3}

Kędelska, E. (1983). Jeszcze o tzw. słowniku Murmeliusza. Studia z Filologii Polskiej i Słowiańskiej, 21, 23-40.

1986

Kędelska, E. (1986). Łacińsko-polskie słowniki drukowane pierwszej połowy XVI wieku i ich stosunek do źródeł czeskich. Zakład Narodowy im. Ossolińskich.

\section{7}

Kędelska, E. (1987). Bartłomiej z Bydgoszczy a Lactifer Vodňanskiego. Studia $z$ Filologii Polskiej i Słowiańskiej, 24, 47-61.

Kędelska, E. (1987). Pierwsze drukowane rozmówki polsko-czeskie. Slavia Occidentalis, 44, 19-27.

1988

Kędelska, E. (1988). W. Wydra, W. R. Rzepka, Chrestomatia staropolska. Teksty do roku 1543, Wrocław 1984 [Recenzja]. Slavia Occidentalis, 45, 147-151.

1989

Kędelska, E. (1989). Pierwsze drukowane słowniki łacińsko-polskie jako źródła Bartłomieja z Bydgoszczy. Studia z Filologii Polskiej i Słowiańskiej, 25, 31-45.

1990

Kędelska, E. (1989-1990). Leksykon Jana Mączyńskiego a łacińsko-czeski słownik Tomasza Reszla. Slavia Occidentalis, 46-47, 89-106.

1992

Kędelska, E. (1991-1992). Nomenklator Piotra Artomiusza z 1591 r. Slavia Occidentalis, 48-49, 93-106.

Kędelska, E. (1992). Osobliwości leksykalne w słowniku Mikołaja Volckmara z 1596 r. Studia z Filologii Polskiej i Słowiańskiej, 30, 49-58. 


\section{3}

Kędelska, E. (1993). Ave Maria i hasła „maryjne” w słownikach polskich i czeskich XVI w. Slavia Occidentalis, 50, 11-23.

Kędelska, E. (1993). Bohemizmy i rutenizmy w słowniku Mikołaja Volckmara z 1596 r. Studia z Filologii Polskiej i Słowiańskiej, 31, 133-146.

Kędelska, E. (1993). Osobliwe zapisy wygłosowego -ř w Leksykonie z 1564 r. (na marginesie kwestii bohemizmów Jana Mączyńskiego). Slavia Occidentalis, 50, 25-33.

1994

Kędelska, E. (1994). M. Szałek, J. Nečas, Czesko-polska homonimia. Słownik, Poznań 1993 [Recenzja]. Slavia Occidentalis, 51, 137-139.

Kędelska, E., \& Łuczak, A. (1994). Bibliografia prac Profesor Ireny Kwileckiej za lata 1953-1994. Slavia Occidentalis, 51, 6-10.

Kędelska, E., \& Łuczak, A. (1994). Jubileusz 40-lecia pracy naukowej Profesor Ireny Kwileckiej. Slavia Occidentalis, 51, 3-6.

1995

Kędelska, E. (1995). Studia nad łacińsko-polską leksykografia drugiej połowy XVI wieku. Instytut Slawistyki Polskiej Akademii Nauk (Slawistyczny Ośrodek Wydawniczy). https://rcin.org.pl/dlibra/publication/18284/edition/7283 /content

Kędelska, E., \& Kwilecka, I. (1995). Profesor Mojżesz Altbauer jako badacz słowiańskich przekładów Biblii: (Uwagi na marginesie książki The Five Biblical Scrolls in a sixteenth-century Jewish translation into Belorussian / Vilnius Codex 262 / with introduction and notes by Moshé Altbauer, Jerusalem 1992). Slavia Occidentalis, 52, 35-40.

Łuczak, A., \& Kędelska, E. (1995). Bibliografia prac Profesor Barbary Szydłowskiej-Ceglowej za lata 1952-1995. Slavia Occidentalis, 52, 12-16.

1996

Kędelska, E. (1996). T. Bešta, Základy polské mluvnice, Praha 1994 [Recenzja]. Slavia Occidentalis, 53, 129-132. 
Kędelska, E., \& Skoczylas-Stawska, H. (1996). Morfologia i słownictwo Namów rozlicznych $\mathrm{H}$. Polyconiusa wobec gwar wieluńskich. W S. Mikołajczak \& A. Sieradzki (Red.), W przyjacielskim kręgu: Prace ofiarowane Profesorowi Zygmuntowi Zagórskiemu w 70. rocznicę urodzin (ss. 200-210). Wydawnictwo WiS.

1997

Kędelska, E. (1997). J. Siatkowski, Slawizmy w utworach śląskich Horsta Bienka, Warszawa 1995 [Recenzja]. Slavia Occidentalis, 54, 142-144.

Kędelska, E. (1997). Przydatność łacińsko-polskich wokabularzy do badań językoznawczych (zalety i ograniczenia). W H. Popowska-Taborska (Red.), Leksyka słowiańska na warsztacie językoznawcy (ss. 117-125). Instytut Slawistyki Polskiej Akademii Nauk (Slawistyczny Ośrodek Wydawniczy).

Kędelska, E. (1997). T. Bešta, Základy polské mluvnice, Praha 1994 [Recenzja]. Opera Slavica, 7(4), 54-58. (Oryginalna praca opublikowana 1996).

1998

Kędelska, E. (1998). Początki slawistyki XVI w. - Mithridates Gesnera i jego polskie źródło. Slavia Occidentalis, 55, 49-68.

Kędelska, E. (1998). Dictionarius Ioannis Murmellii variarum rerum; [Francisci Mymeri] Dictionarium trium linguarum, oprac. W. Gruszczyński, Biblioteka Tradycji Literackich, pod red. W. Waleckiego, nr 13 A i B, Wydawnictwo Naukowe DWN, Kraków 1997 [Recenzja]. Slavia Occidentalis, 55, 169-172.

Kędelska, E. (1998). J. Siatkowski, Czesko-polskie kontakty językowe, Warszawa 1996 [Recenzja]. Slavia Occidentalis, 55, 167-169.

\section{9}

Kędelska, E. (1999). Informacje o Słowianach w renesansowym słowniku Calepina - opracowanym przez Konrada Gesnera. W J. Świdziński (Red.), Język, literatura, kultura Słowian dawniej i dziś (Cz. 2, ss. 63-69). Uniwersytet im. Adama Mickiewicza.

Kędelska, E. (1999). Nowa edycja Słownika Bartłomieja z Bydgoszczy. Studia $z$ Filologii Polskiej i Słowiańskiej, 35, 41-53. 
Kędelska, E., Kwilecka, I., \& Łuczak, A. (1999). Słownik Bartłomieja z Bydgoszczy - wersja polsko-łacińska: Cz. 1. A-G. Instytut Slawistyki Polskiej Akademii Nauk (Slawistyczny Ośrodek Wydawniczy). https://hdl.handle.net $/ 20.500 .12528 / 1083$

\section{1}

Kędelska, E. (2001). Nieznane edycje słowników: Mymera z 1530 r. i Murmeliusza z 1526 r. Studia z Filologii Polskiej i Słowiańskiej, 37, 61-79.

\section{3}

Kędelska, E. (2003). Seria czterech książek z polskimi przekładami biblijnymi Tomasza ze Zbrudzewa w opracowaniu I. Kwileckiej [Recenzja książek: Perykopy wielkopostne w przekładzie Tomasza Łysego ze Zbrudzewa; Brulion przekładu pierwszych trzech ksiag Biblii pióra Tomasza ze Zbrudzewa, czyli tzw. Mamotrept gnieźnieński; Apokalipsa św. Jana w przekładzie Tomasza ze Zbrudzewa; Brulion przekładu Biblii pióra Tomasza ze Zbrudzewa, cz. II. Księgi: Liczb, Powtórzonego Prawa, Pieśni nad Pieśniami I. Kwileckiej]. Slavia Occidentalis, 60, 141-144.

Kędelska, E., Kwilecka, I., \& Łuczak, A. (2003). Słownik Bartłomieja z Bydgoszczy - wersja polsko-łacińska: Cz. 2. H-M. Instytut Slawistyki Polskiej Akademii Nauk (Slawistyczny Ośrodek Wydawniczy). https://hdl.handle.net $/ 20.500 .12528 / 1083$

\section{4}

Kędelska, E. (2004). Dzieje poznańskiej Pracowni Języków Zachodniosłowiańskich. W H. Handke (Red.), 50 lat slawistyki w Polskiej Akademii Nauk (1954-2004): Ksiegga jubileuszowa Instytutu Slawistyki PAN (ss. 161-170). Instytut Slawistyki Polskiej Akademii Nauk (Slawistyczny Ośrodek Wydawniczy).

\section{5}

Kędelska, E. (2005). Dzieje poznańskiej Pracowni Języków Zachodniosłowiańskich. Studia z Filologii Polskiej i Słowiańskiej, 40, 175-184.

Kędelska, E. (2005). Jubileusz pięćdziesięciolecia slawistyki w Polskiej Akademii Nauk: Od Zakładu Słowianoznawstwa do Instytutu Slawistyki PAN. Slavia Occidentalis, 62, 191-193. 
Kędelska, E., Kwilecka, I., \& Łuczak, A. (2005). Słownik Bartłomieja z Bydgoszczy - wersja polsko-łacińska: Cz. 3. N-Pleć. Instytut Slawistyki Polskiej Akademii Nauk (Slawistyczny Ośrodek Wydawniczy). https://hdl.handle.net $/ 20.500 .12528 / 1083$

\section{9}

Kędelska, E. (2009). Nowo odkryta edycja dykcjonarza Franciszka Mymera z pierwszej połowy XVI wieku w zbiorach Biblioteki Narodowej. Roczniki Biblioteczne, 53, 81-102.

Kędelska, E., Kwilecka, I., \& Łuczak, A. (2009). Słownik Bartłomieja z Bydgoszczy - wersja polsko-łacińska: Cz. 4. Plemię-Pytlowany. Instytut Slawistyki Polskiej Akademii Nauk (Slawistyczny Ośrodek Wydawniczy). https://hdl .handle.net/20.500.12528/1083

\section{2}

Jankowiak, L. A., \& Kędelska, E. (2012). Adama Stanisława Krasińskiego zapomniany Słownik synonimów polskich i jego poprzednicy. Studia z Filologii Polskiej i Słowiańskiej, 47, 39-67. https://doi.org/10.11649/sfps.2012.002

Kędelska, E., Kwilecka, I., \& Łuczak, A. (2012). Słownik Bartłomieja z Bydgoszczy - wersja polsko-łacińska: Cz. 5. R-Stracenie. Instytut Slawistyki Polskiej Akademii Nauk (Slawistyczny Ośrodek Wydawniczy). https:// hdl.handle.net/20.500.12528/1083

\section{9}

Jankowiak, L. A., Kędelska, E., \& Łuczak, A. (2019). Słownik Bartłomieja z Bydgoszczy - wersja polsko-łacińska: Cz. 6. Strach-Żyzny. Instytut Slawistyki Polskiej Akademii Nauk. https://hdl.handle.net/20.500.12528/1083 


\title{
List of Publications by Dr hab. Elżbieta Kędelska
}

\author{
Summary
}

The paper provides a list of publications by Dr hab. Elżbieta Kędelska.

\section{Wykaz publikacji dr hab. Elżbiety Kędelskiej}

\author{
Streszczenie
}

Artykuł stanowi wykaz publikacji dr hab. Elżbiety Kędelskiej.

Keywords: Elżbieta Kędelska; bibliography

Słowa kluczowe: Elżbieta Kędelska; bibliografia

Arleta Łuczak, Institute of Slavic Studies Polish Academy of Sciences, Warsaw, Poland ORCID: https://orcid.org/0000-0002-3076-7144

Correspondence: arleta.luczak@ispan.waw.pl

The preparation of this article was financed within the statutory activities of the Institute of Slavic Studies, Polish Academy of Sciences.

Competing interests: The author has declared that she has no competing interests. 